\title{
The Impact of Dividend Policy on Stock Prices in Money Deposit Banks in Nigeria (1994-2019)
}

\author{
ALASHE, Abdulganiyy Kayode ${ }^{1}$, ISHOLA, Joseph Olaniyi ${ }^{2}$ \\ ${ }^{I}$ Department of Accountancy, School of Management and Business Studies, Lagos State Polytechnic, Ikorodu, Nigeria \\ ${ }^{2}$ Department of Accountancy, School of Part Time Studies, Lagos State Polytechnic, Ikorodu, Nigeria
}

\begin{abstract}
The tenacity of this study was to study the empirical influence of dividend policy on stock prices in Nigerian deposit banks. This study, which required the acquisition of historical data, used post-facto research. The population of the study was the twenty-two (22) money deposit banks in Nigeria. Secondary data through annual reports (1994-2019) for a period of 25 years was obtained from the selected banks. The Statistical Package for the Social Sciences software were used to describe observations through descriptive statistics, such as minimum, maximum, means and standard deviation, while the relationship between stock price and dividend policy was investigated through the use of inferential statistics such as regression analysis and correlation technics. The statistics showed a favorable and substantial influence on the stock price of a dividend per share (DPS) $(=0.1971 ; p$ 0.05). Earnings per share (EPS) were considerably beneficial to the share price $(=0.0404$; p0.05), however a lower positive influence was shown in the payout ratio $(\mathrm{DPR})(=0.9227 ; \mathrm{p}>0.05)$. During the study period, dividend policy had an influence on the stock prices of Nigerian deposit money institutions, according to the findings. The study therefore recommended that companies should strive for strong adherence to shareholders' interests in adopting dividend policies that maximize shareholder value by management, among other things.
\end{abstract}

Keywords: Dividend, dividend policy, earnings per share, dividend per share, dividend payout ratio

\section{INTRODUCTION}

$\mathrm{T}$ The dividend decision is one of three fundamental decisions that a financial manager must make, the other two being investment and financing decisions (Muhammad, 2016). The board of directors recommends the dividend decision at the annual general meeting (Akinwunmi \& Akinola, 2019). The board of directors is faced with the challenge of balancing the requirement to finance future expansion with the need to retain appropriate liquidity and satisfy shareholder expectations. As a result, decisions on the extent of profit retention, cash or stock dividend, buyback of market shares, and the amount and timing of dividends must be taken (Al-Masum, 2014). As a result, while determining an appropriate dividend policy, managers examine not only the current year's profit but also predicted future earnings and the company's ability to maintain a stable dividend rate while taking systematic growth into account (Amuche, 2014; Ashamu, Abiola \& Badmus, 2010).

Dividend policy has been described differently by different scholars. According to Akinsulire (2010), the dividend policy is the exchange of retained income for cash or shareholders. The dividend policy established by Adediran and Alade (2013) for management as an exclusive discretion to determine the shareholders' portion of the profit and the percentage to meet internal needs. The phrase refers, according Attah-Botchwey (2014), to the managerial principle for the determination as dividend for a certain financial year of the fraction of the net profit of a company after taxes paid to the residual shareholder. The dividend policy was discussed in the financial literature according to Nwamaka and Ezeabasili (2017). In making policy decisions on dividends academics and researchers have produced several theoretical models to describe variables that management should take into consideration.

The objective of companies is to maximize profit and value of shareholders' investment within the company, according to Gul, Sajid, Razzaq, Iqbal and Bilal Khan (2012). Managers are working to this purpose by taking investments, finances and dividends decisions. The selection of investment is the choosing of projects with an incremental net actual value (Jecheche, 2012). Decisions on financing consist of adopting a capital structure that decreases the capital cost of the firm; decisions on dividends state the value investors and future investors obtain from their investment in the enterprise (Hashemijoo, Ardekani \& Younesi, 2012). Aside from investment and financial considerations, management must decide whether or not to pay earnings to shareholders on a regular basis, reducing the agency problem (Jecheche, 2012). The question of whether paying out earnings creates value for shareholders, on the other hand, remains unsolved. This dilemma is a finance literature misconception; a dividend payment provides cash flow to shareholders while lowering the firm's resources for investment.

Dividend policy is still one of the most divisive topics in corporate finance. Financial economists have been calculating and studying corporate dividend policy and earnings in relation to Nigerian bank stock prices for a long time (Amidu, 2007). Dividend policy research and profit research has shown that not only does payment policy generally elusive theory, but that company dividend practices vary over time, between companies and between countries. In addition to the time constraints, dividend policies fluctuate throughout countries, notably between industrialized and emerging financial institutions. 
The majority of the study in Nigeria instead focuses on the reasons for dividend policy and their effect on the production of wealth (Akinwunmi \& Akinola, 2019). A major factor is the link between the dividend policy and the stock price, with the focus on these two aspects of the dividend policy alone. Studies in Nigerian deposit money institution in particular on the relationship of dividend yield and equity prices, income and equity prices and dividend payout ratio and equity prices are uncommon.

With this in mind, this study was carried out to evaluate the influence of the stock prices and dividend policy in Nigeria's money deposit banks during a 25-year period (1994-2019). This study specifically attempts to:

i. describe the characteristics of dividend policy variables

ii. investigate the impact of dividend policy on Nigerian deposit money bank stock prices.

iii. examine the relationship between dividend policy and Nigerian deposit money bank stock prices.

\section{LITERATURE REVIEW}

\section{Dividend and Stock Price in Emerging Markets}

Emerging economies are the fastest growing economies of the world. They are in the transition phase in their development process. India is one of the emerging economies. The Indian stock market as most of the other emerging economies stock markets is growing rapidly and exhibits volatility die to growth prospects (Habib, Kiani \& Arif-Khan, 2012).

The empirical studies of signaling theories on these countries provide different results. Discussion on these studies follows: Lashgari and Ahmadi (2014) while studying Chinese market observed a positive relationship between changes in profits and stock returns measured over short intervals of time. Further, it was realized that the signaling effect of dividend announcements along with earnings embellish the signal from earnings.

Detailed market reaction to Kala Lumpur Bursary dividend releases for the period 1996-1999 Attah-Botchwey (2014) (KLSE). The proof refutes the hypothesis of signaling. Jecheche (2012) has employed a semi-strong form of stock price efficiency to examine event studies in the form of dividend announcements. From July 2004 to June 2007, he examined cash, stock and simultaneous dividend notices for 79 businesses registered at the Karachi Bourse. The influence of cash dividend announcements on stock prices is statistically insignificant, according to Attah-Botchwey (2014) and Jecheche (2012). They also argued that returns are largely negative for the 41-day window, which they attribute to the tax effect on cash dividends.

\section{Shareholders Earnings (EPS) and the Firm}

Financial structure decisions, according to Salman, Lawal, and Anjorin (2015), provide chances for firms to generate importance for shareholders; however, these chances are frequently overlooked due to the striving in recognizing and enumerating the factors on the left hand side of the balance sheet that affect shareholder value, especially for companies with complex liquidity structures. They argue that while executives frequently have a rough sense of whether the general financial structure is "about right," they lack the skills to evaluate substitute liability arrangements. As a result, liability choices are typically based on solely cosmetic concerns, precise conformity to all rating agency requirements, and competitive benchmarking.

Sharif, Ali, and Jan (2015) have agreed on a significant challenge to the management of debt as a source of capital, first as the debt types should, in order to achieve the lowest explicit costs and less damaging consequences for the enterprise and its holders, be selected using EPS variability, and, secondly, since the overall financial framework should be developed at the lowest cost.

The optimum financial structure will have a lower ratio of debt to capital than the debt-to-equity ratio required for revenues per share to optimize Akinwunmi and Akinola (2019). This is because the valuation of a stock market takes into account the potential risks associated with the operations of EPS, which are forecasted in future.

\section{Dividends, Stock Prices, and Semi-Strong Market Efficiency}

Despite a wide range of theoretical and empirical studies on the importance and the link between stock prices and dividends, the conclusions remain unknown. The relevance of dividends and thus the desire of investors to achieve them is emphasized by Abdullah (2014). Baah, Tawiah, and Eric (2014) assessed and found that the policy on dividends had no influence on stock prices. The investors have to decide whether to hold high or low-yield securities; in both circumstances, returns are the same. The hypothesis of signaling or information content has been endorsed by Duke, Ikenna and Jatmiko (2015), as well as by (2016). The information content of dividend theory was endorsed by Karnawi (2017), Mirza and Afza (2014) and Obamuyi (2017) (2013).

Dividends can minimize or exacerbate agency conflict between management and shareholders, according to Salman, Lawal, and Anjorin (2015). After supporting all efforts with positive net present values, a company's management boosts dividends to shareholders and distributes any residual cash. As a result, an increase in dividend distribution leads to a rise in stock prices, and vice versa.

Value Creation by Shareholders and its Relationship to Dividend Policy Decisions

Various research studies have found that when a dividend policy is set and maintained carefully, it can have a major impact on a company's future worth (Solomon, Memba \& Muturi, 2016; Shehzad \& Ismail, 2014). Profit maximization is a commonly accepted corporate goal since it reconciles the many, and often competing, interests of the stakeholders. A 
business that is still operating must endeavor to improve its cash-generating capacity.

The capacity of a firm to dispense cash to its many constituencies is determined by its capability to create cash through normal operations and to collect any additional funds required from other sources. The two most common external forms of funding are debt and equity. Borrowing power and stock market value are both influenced by a company's ability to generate cash. The second type of funding, equity finance, is directly influenced by the market value of the shares. The sophisticated the share price, the less dilution will be endured by current shareholders for a given level of money necessary.

As a result, boosting the value of the shares gives management the financial authority to deal successfully with corporate claimants. Shareholders can be rewarded with dividends and capital gains, which will raise the value of their shares.

\section{THEORETICAL FRAMEWORK}

\section{Dividend Irrelevance Theory}

The argument on dividends politics has lasted since the insignificance theory became famous to Miller and Modigliani (1961). Miller and Modigliani contend that the perfect equity market without personal and corporate taxes, stable investment policies, no transaction costs and rational investors does not have any connection between dividend policy and share price. In corporate finance, the Miller and Modigliani (MM) theory has played an important role. MM theory is mentioned in practically every piece of corporate finance literature (Al-Malkawi, 2007; Al-Malkawi, 2008; Fodio, 2009; Nnamdi, 2009; Dengelo \& De Angelo, 2004; De Angelo, De Angelo \& Skinner 1996; Pandey, 2005; Pani, 2008; Michael \& Benson, 2014; Eric, 2012). The link between this theory and this study is that they both concern dividends, as this theory is about dividend policy. The impact of dividend policy on stock price volatility is investigated in this study. Despite the fact that the theory does not explain stock volatility, there is a strong connection between the two in terms of dividend policy.

\section{Agency Cost Theory}

The expense of conflict of interest between managers and shareholders is known as agency cost. It's also the price of a shareholder-creditor conflict of interest. According to Zayol, Mya, and Muolozie (2017), agency cost emerges when ownermanagers sell a portion of their holdings to third parties. According to Miller and Modigliani, managers are perfect agents of the shareholders, and there are no agency costs between them. According to Al-Malkawi (2007), managers may engage in activities that cost shareholders money, such as making investments with a negative net present value and paying themselves excessive compensation. Easterbrook (2004) and (Ponsian, Prosper, Yuda, and Samwel 2015) created agency cost in terms of dividend policy. They suggest that dividend policy can help agencies save money.
Shareholders, they argue, demand funds that can be utilized to help companies expand. The cash flow of the company is reduced by the dividend given to shareholders, prompting managers to raise funds from the capital market. Capital market funds are closely monitored. This eliminates shareholder oversight of managers, hence diminishing oversight.

\section{The Bird in Hand Theory}

The bird-in-hand idea preceded Miller and Modigliani in accordance with Al-Malkawi (2007) (1961). Investors like, according to the bird in hand argument, dividends in a world of insecurity and asymmetry of knowledge as a bird in their hand worth more than two in their bush. The big dividend will lower capital cost, which will enhance the stock price. The price will be reduced.

This notion, according to Al-Malkawi, has garnered little support. Gordon is one of the proponents of this hypothesis (1959). The bird in hand idea gains traction due to the irrelevance theory's indeterminacy (Al-Malkawi, 2007). Apart from being related directly through dividend, this theory and this study are also linked by stock price. An increase in volatility indicates a low stock price, while a reduction in volatility indicates a high stock price. As a result, if low dividends raise stock prices, this theory's forecast and the model's prediction contradict each other.

In the 2014 Abu Dhabi Securities Exchange, Al-Shawawreh held a survey of business executives. All of the main elements that determine its dividend policy are external economic considerations, as well as the present capital market and lending conditions, and, according to the poll, the constraints on its debt providers and the current financial market problems.

According to this hypothesis, an increase in risk eventually leads to a decrease in price. According to Habib, Kiani, and Arif-Khan (2012), the rate of return effect has grown. According to the idea, shareholders in a low-dividend-paying corporation have a high anticipation of the company's growth. In the not-too-distant future, growth expectations will be replaced by uncertainty. According to the theory, dividend policy and stock price volatility have a negative association. Uncertainty is linked to the far future. This could be the foundation of this theory. In the short term, the theory recommends a low degree of uncertainty, whereas in the long term, it proposes a high level of uncertainty.

A search was carried out by 123 Kuwaiti listed on Kuwait Bonds to assess the elements that influence dividend policy in Kuwait, Zakaria, Muhammad and Zulkifli (2012). (KSE). The survey findings show that future income is the keyfactor of the current dividend, although the liquidity in Kuwait is another major dividend component. The dividend paying corporate managers on the Indonesian Stock Exchange (IDX) performed a survey by Baker and Powell (2012) in order to learn about the variables affecting dividend policy, dividend problems and explanations for dividend. Research shows that 
earnings stability, current earnings levels and forecasted future profit are the most important indicators for dividends. The study also revealed that Indonesian CEOs believe that dividend policy affects their company's value.

Joshi (2012) examined managers' prospects for the elements that affect dividend choices in Nigerian publicly traded businesses. It shows that previous patterns of dividends, current income levels and financial leverage, alternative sources of available funds, liquidity constraints such as availability of cash, growth and opportunities for investment, as well as liquidity constraints such as cash availability, all have important implications on Nigerian companies' dividend decisions.

Al-Malkawi (2008) explored if, as a result of the tax reduction in capital gains, the association between US policy on dividends and stock return volatility in the course of time has changed. They estimated their results, using common stock information from 1967 to 1986 and the symmetrical model, to instruct various trades and techniques of investment.

\section{METHODS}

This study uses an ex-post-facto research design, which entails the systematic collection of historical data followed by a critical examination. All deposit money banks (DMBs) in Nigeria are included in the study's population. As of March 2019, Nigeria has twenty-two (22) deposit money banks, the majority of which have branches scattered over the thirty-six (36) states of the federation and the Federal Capital Territory, with their headquarters in Lagos.

The annual reports of selected quoted deposit money banks and the NSE's daily official lists for the period 1994-2019 were used to compile the data for this study. The cash flow accounts of the banks provided information on dividend payments. The information on retained earnings was taken from the balance sheets and the statement of changes in equity, while the market share price was taken from the NSE's daily official lists for the time period under consideration.

Descriptive statistics such as minimum, maximum, means, and standard deviation were used to describe the observations, while inferential statistics involved the use of the Ordinary Least Squares (OLS) model and pair wise correlation techniques through the use of the Statistical Package for Social Science (SPSS) OLS was chosen since the computational technique is straightforward and the data requirements are modest as it was a panel data.

The stock price (SP) is made a function of other explanatory variables such as earnings per share (EPS), dividend per share (DPS), and payout ratio (POR) while defining the model. The following is the model used:

$\mathrm{SP}=\mathrm{F}($ EPS, DPS, POR $)$

The model specification is therefore represented in a linear equation form as:
Where:

$$
\begin{aligned}
& \text { EPS }=\text { Earnings Per Share } \\
& \text { DPS }=\text { Dividend Per Share } \\
& \text { POR }=\text { Payout Ratio } \\
& \beta 0, \beta 1, \beta 2, \beta 3 \text { are regression parameters; } \\
& \mu \text { is error term }
\end{aligned}
$$

It is expected that $\beta 1, \beta 2, \beta 3>0$. This implies that stock price will increase when there is an increment in EPS, DPS and POR

\section{RESULTS AND DISCUSSION}

Table 1 reveals the descriptive statistics of the data analysis. As observed, Stock Price (SP) has a mean value of (16.8661), minimum value of (1.2) and maximum value of (33). This shows that the market price has increased moderately within the study period. The standard deviation of (11.64347) is considerably low and suggests that market price across the sample size exhibits a wide dispersion around the mean. Dividend per Share (DPS) has maximum and minimum values of (25) and (100) respectively with a mean value of (42.94444). The standard deviation of (22.4826) shows a moderate deviation around the mean. The Earnings per Share (EPS) has maximum and minimum value of (24) and (431) respectively with a standard deviation of (100.0341) which shows moderate significant deviation from the mean value of (195.3333). The Payout Ratio (POR) variable has mean value of (0.1759287), a maximum value of (0.7092199) and a minimum value of $(-1.041667)$. The standard deviation of (0.3514557) shows a significant dispersion from the mean.

Table 1: Descriptive of the study variables

\begin{tabular}{|c|c|c|c|c|c|}
\hline Variable & Observation & Mean & $\begin{array}{c}\text { Standard } \\
\text { Deviation }\end{array}$ & Minimum & Maximum \\
\hline SP & 24 & 16.86 & 11.64 & 1.2 & 33 \\
\hline DPS & 24 & 42.94 & 22.48 & 25 & 100 \\
\hline EPS & 24 & 195.33 & 100.03 & 24 & 431 \\
\hline POR & 24 & 0.17 & 0.35 & 1.04 & 0.70 \\
\hline
\end{tabular}

Source: Authors' Computation, 2021.

Table 2 reveals the multiple regression analysis of the variables employed in this study. The $\mathrm{R}^{2}$, and calculated Fvalue indicated a significance relationship given $R^{2}=0.7483$. This implies that the predictive power of the independent variable (Dividend Policy) as used to explain variation in the dependent variable Stock Price is only about $74.83 \%$ with an adjusted $\mathrm{R}^{2}$ of (0.6872). The combined $\mathrm{P}$ value of 0.0020 and F-value of 31.54 shows there is significant relationship and effect between the variables examined. The regression equation is as shown below:

$\mathrm{SP}=-23188.68+0.1970505 \mathrm{DPS}+0.0404532 \mathrm{EPS}$

$0.9227107 \mathrm{POR}$ 4.1

SPit $=\beta 0+\beta 1$ EPSit $+\beta 2$ DPSit $+\beta 3$ PORit $+\mu$ 
The result shows that DPS Shows a marginal positive contribution of 0.1970505 , EPS contributed a positive 0.0404532 to the variation in SP while POR indicated a positive but marginal contribution of 0.9227107 to changes in SP

Table 2: Regression Analysis Showing the Relationship between Dividend Policy and Stock prices in Nigeria Banks

\begin{tabular}{|c|c|c|c|c|c|c|}
\hline Dependent variables & Independent variables & Coefficient & Standard Error & $\mathrm{T}$ & $\mathrm{p}>|\mathrm{t}|$ & {$[95 \%$ conf. interval] } \\
\hline SP & DPS & .1970 & .1516 & 1.3 & 0.015 & $-.1282573 \quad .5223583$ \\
\hline & EPS & .0404 & .0282 & -.143 & 0.10 & $-.1010175 \quad .0291112$ \\
\hline & POR & .9227 & 10.0359 & -0.09 & 0.928 & $-22.44775 \quad 20.60233$ \\
\hline
\end{tabular}

Source: Authors' Computation, 2021

Table 3 shows the pair wise correlation test between the variables and it indicates similar result given correlation between Stock Price (SP) and other explanatory variables. The coefficient of correlation (R) between Dividend per Share (DPS) and Stock Price (SP) is 0.5502, an indication of moderate relationship. EPS has a high positive correlation coefficient of 0.7399 with SP and the Payout Ratio (POR) has moderate correlation with SP.

Table 3: Pair wise correlation between Dividend Policy and Stock price in Nigeria Banks

\begin{tabular}{|c|c|c|c|c|}
\hline & SP & DPS & EPS & POR \\
\hline SP & 1.0000 & & & \\
\hline DPS & 0.5502 & 1.0000 & & \\
\hline EPS & 0.7399 & -0.0390 & 1.0000 & \\
\hline POR & 0.1105 & $0.5997 *$ & 0.0290 & 1.0000 \\
\hline
\end{tabular}

Source: Authors' Computation, 2021

\section{Test of Hypotheses}

H01: The dividend per share of Nigerian deposit money banks has no substantial impact on stock prices.

Dividends per share had a positive impact on stock price, given $=001971$ and $p=0,015$ in Table 2, (less than 0.05). This rejects the zero hypothesis and accepts the alternative. This has a huge effect on Nigerian stock price of deposit money banking dividends per share.

H02: Nigerian deposit money banks have no relevant link between the earnings per share and stock prices. In Table $2=$ 0.0404 and $p=0.010$ earnings were positive on the inventory price per share (less than 0.05). This rejects the null hypothesis and accepts the alternative hypothesis. As a consequence, Nigerian deposit money banks' earnings per share and stock prices correlate strongly.

H03: The payout rate of dividends has little effect on Nigerian banks' stock values.

The payout dividend ratio had a favorable influence on the stock price, given $=0.9227$ and $\mathrm{p}=0.928$ in Table 2 , (higher than 0.05). This allows for the acceptance of a null hypothesis, while rejecting the alternative hypothesis. The payout ratio therefore has no effect on Nigerian deposit-money institutions' stock prices.

\section{DISCUSSION OF THE RESULTS}

The analysis shows that the P-value of 1.0000, the F-value of 0.0020 , the R-Squared of 0.7483 , the modified R-Squared of 0.6872 have a substantial association between the policy of the bank dividend and the stock price. In addition, after assessment of the dividend per share's influence on stock prices, the dividend per share was found to have a positive effect on stock price with $\mathrm{p}=0,015$ and $=0,1971$. (less than 0.05). The study also looked at the association between EPS and stock prices. The result given $=0.0404$ and $\mathrm{p}=0.010$ indicated a positive influence on the stock price on earnings per share (less than 0.05). The study examined the link between the payout ratio (POR) and share prices. The findings showed a favorable impact on the stock price, given $=0.9227$ and $\mathrm{P}=0.928$. (greater than 0.05). The finding of this work was the same of (Emeka \& Ogochukwu, 2021) which indicated that Dividend Payout, Dividend Per Share \& Dividend Yield have significant and positive impact on firms share price at $1 \%$ significant level also with Ogbuagu, (2020) which instituted that dividend policy has exercised significant influence on firms' performance over the years.

\section{CONCLUSION AND RECOMMENDATIONS}

The study's main goal is to look at the influence of dividend policy on stock prices in Nigerian banks over a twenty-fouryear timeframe (1994-2019). From the findings, the study demonstrated and concluded that dividend per share had a progressive effect on stock price. Furthermore, the study concluded and revealed that earnings per share had a favorable effect on stock price, and finally, the analysis concluded that the dividend payout ratio had a favorable effect on stock price. Dividend policy has an effect on stock prices in the Nigerian deposit money bank, according to the study. The following suggestions were offered in light of the aforesaid findings: to address the agency problem, managers should operate in the best interests of investors by providing complete information regarding the firm's dividend policies. Dividend announcements, it is said, provide investors with information about the firm's value possibilities. As a result, stock prices tend to rise when a dividend increase is declared, 
but fall when a drop or omission is revealed. According to the findings, management should pay close attention to the interests of shareholders when deciding on dividend policies that will enhance shareholder value. Managers are the ones who have decision-making authority in a firm. The principles are the shareholders, who are the company's owners, and the managers are their agents. As a result of the principal-agent relationship between shareholders and managers, managers should and must behave in the best interests of shareholders in order to achieve the firm's wealth maximization goals. The report also recommended that Nigerian businesses, particularly banks, adopt a dividend payment policy that involves distributing dividends on an annual basis. Dividends are paid to influence share prices, according to the classical school of thought, and the market price of equity is a representation of the current value of predicted cash dividends that the stock can generate. However, the outcomes of this study reveal that Nigerian banks' payment practices have no effect on stock prices, which would attract investors' attention and boost the value of equities.

\section{REFERENCES}

[1] Abdullah, A.M (2014). Dividend Policy and Its Impact on Stock Price - A Study on Commercial Banks Listed in Dhaka Stock Exchange. Global Disclosure of Economics and Business, 3, (1), 9-17.

[2] Adediran S. A., \& Alade S. O. (2013). Dividend Policy and Corporate Performance in Nigeria. American Journal of Social and Management Sciences, 4(2), 71-77.

[3] Akinsulire, O. (2010). Financial Management. Ceemol Nigerian Ltd, Lagos Nigeria.

[4] Akinwunmi, A. \& Akinola, A. (2019). Dividends policy and market values by shares in selected quoted deposit money banks in Nigeria. International Journal of Management Sciences and Business Research, 8 (9), 1-11.

[5] Al-Masum, A. (2014). Dividend Policy and Its Impact on Stock Price: A Study on Commercial Banks Listed in Dhaka Stock Exchange. Global Disclosure of Economics and Business, 3(1), 921.

[6] Al-Malkawi, (2008). Factors Influencing Corporate Dividend Decision: Evidence from Jordanian Panel Data. International Journal of Business, 13 (2), 1-11.

[7] Al-Malkawi, H.N. (2007). Determinants of Corporate Dividend Policy in Jordan: An Application of the Tobit Model. Journal of Applied Accounting Research, 23, 44-70.

[8] Al-Shawawreh, F.K. (2014). The Impact of Dividend Policy on Share Price Volatility: Empirical Evidence from Jordanian Stock Market. European Journal of Business and Management, 6(38), 133-142

[9] Amuche, A.E. (2014). The Impact of Dividend Policy and Earnings on Stock Prices of Nigeria Banks. Master of Science (M.Sc.) Thesis, University of Nigeria Nsukka.

[10] Ashamu, S.O., Abiola, J.O, \& Badmus, S.O. (2010). Dividend Policy as Strategic Tool of Financing in Public Firms: Evidence from Nigeria. European Scientific Journal, 8(9), 1-24.

[11] Attah-Botchwey, E. (2014). The Impact of Dividend Payment on Share Price of Some Selected Listed Companies on the Ghana Stock Exchange. International Journal of Humanities and Social Science, 4, 9(1), 179-191

[12] Baah, B.K., Tawiah, R. \& Eric, O.F. (2014). Industry sector determinants of dividend policy andits effect on share prices in Ghana. International Journal of Economics, Business and Finance, 2 (5), 1-19.

[13] Baker, H. K. \& Powell, G. E. (2012). How Corporate Managers view Dividend Policy? Quarterly Journal of Business and Economics, 38(2), 17- 35 .
[14] Baskin, J. (1999). Dividend Policy and the Volatility of Common Stock. Journal of Portfolio Management, 15 (3), 19-25.

[15] De Angelo, H. \& De Angelo, L. (2004). The Irrelevance of the MM Dividend Irrelevance Theorem. Journal of Financial Economics, 70, 1-30.

[16] De Angelo, H., De Angelo, L. and Skinner, D. J. (1996). Are Dividend Disappearing? Dividend Concentration and the Consolidation of Earnings. Journal of Financial Economics, 3, 130 .

[17] Duke, S.B., Ikenna, N.D., \&Nkamare, S. E. (2015). Impact of Dividend Policy on Share Price Valuation in Nigerian Banks. Archive of Business Research, 3(1), 156-170.

[18] Easterbrook, F., H. (2004). Two agency-cost explanations of dividends. American Economic Review, 74(4), 650-659.

[19] Emeka, O. L., \& Ogochukwu, O. N. (2021). Impact of Dividend Policy on Share Price of Listed Ict Firms in Nigeria. International Journal of Academic Research in Business and Social Sciences, 11(9), 1489-1502.

[20] Eric, B. (2012). The Effects of Dividend Policies on Stock Prices. Demand Media Google.

[21] Fodio, M.I. (2009). The Dividend Policy of Firms Quoted on the Nigerian Stock Exchange: An Empirical Analysis. African Journal of Business Management, 3(10), 555-566.

[22] Gordon, M.J. (1959). The Investment, Financing, and Valuation of the Corporation. Homewood, Illinois: Irwin Publishers.

[23] Gul, S., Sajid, M., Razzaq, N., Iqbal, M.F., \& Bilal Khan, M. (2012). The Relationship between Dividend Policy and Shareholder's Wealth (Evidence from Pakistan). Economics and Finance Review, 2(2), 55 - 59 .

[24] Habib, Y. Kiani, Z.I., \& Arif Khan, M. (2012). Dividend Policy and Share Price Volatility: Evidence from Pakistan. Global Journal of Management and Business Research, 12 (5), 79-86.

[25] Hashemijoo, M. Ardekani, A.M. Younesi, N. (2012). The Impact of Dividend Policy on Share Price Volatility in the Malaysian Stock Market. Journal of Business Studies Quarterly, 4(1), 111129

[26] Jatmiko, D.P. (2016) The Influence of Agency Cost, Market Risk, and Investment Opportunities on Dividend Policy. International Journal of Management and Commerce Innovations, 3 (2), 68-75.

[27] Jecheche, P. (2012). Dividend policy and stock price volatility: A Case of the Zimbabwe Stock Exchange. Journal of Comprehensive Research Accounting \& Finance, 1-12.

[28] Joshi, R. (2012). Effects of Dividends on Stock Prices in Nepal. NRB Economic Review, 24(2), 61-75.

[29] Karnawi, K, (2017). Analysis of the effect of return on equity and debt to equity ratio on stock price on cement industry listed in Indonesia stock exchange in the year of 2011-2015. Journal of Business and Management, 19(5), 66-76.

[30] Lashgari, Z., \& Ahmadi, M. (2014). The Impact of Dividend Policy on Stock Price Volatility in the Tehran Stock Exchange. Kuwait Chapter of Arabian Journal of Business and Management Review, 3(10), 273-283.

[31] Michael, O.O., \& Benson, A.K. (2014). The Impact of Dividend Policy on Stock Prices of Quoted Firms in Nigeria. International Journal of Economics, Commerce and Management, 3(2), 30-41

[32] Miller, M.H., and Modigliani, F. (1961). Dividend policy, growth, and the valuation of shares. The Journal of Business, 34(4), 411433.

[33] Mirza, H. \& Afza, T. (2014). Impact of Corporate Cash Flow on Dividend Pay-outs: Evidence from South Asia. Middle-east Journal of Scientific Research, 19 (4), 472- 478.

[34] Muhammad, S.N. (2016). Effect of dividend policy on stock prices: Analysis of listed Banks in Nigeria. International Journal of Business and Technopreneurship, 6(3), 379-392.

[35] Nnamdi, S.I., (2009). Corporate Earnings and Dividend Pay-out in Nigeria. A Seminar Paper Presented to the Department of Banking and Finance in Fulfilment of the Award of PhD in Finance, Abia State University Uturu.

[36] Nwamaka, O.C. \&Ezeabasili, V. (2017). Effect of Dividend Policies on Firm Value: Evidence from quoted firms in Nigeria. International Journal of Management Excellence, 8(2), 956-967. 
[37] Obamuyi. T. M. (2013). Factors Influencing Investment Decisions in Capital Market: A study of Individual investors in Nigeria. Organizations and Markets in Emerging Economies, 4(1), 7.

[38] Ogbuagu, N. (2020). Effect of dividend policy on firms performance. Journal of Accounting, Business and Social Sciences, 3(2), 1-18

[39] Pandey, I.M. (2005). Financial Management. New Delhi: Vilkas Publishing House PVT Ltd.

[40] Pani, U. (2008). Dividend Policy and Stock Price Behaviour in Indian Corporate Sector: A panel data approach. Indian institute of technology.

[41] Ponsian, N., Prosper, K., Yuda, T. \& Samwel, G. (2015) Relationship between Dividend policy and Share Price. Archives' of Business Research, 3(3), 11-20.

[42] Salman, A.Y., Lawal, A.A. \& Anjorin, S.Y. (2015). The Impact of Dividend Policy on the Share Price of Selected Quoted Firms in Nigeria. The Institute Of Chartered Accountants of Nigeria 1st Academic Conference on Accounting and Finance.

[43] Sharif, I. Ali, A. \& Jan, F.A. (2015). Effect of Dividend Policy on Stock Prices. Journal of Management Info, 6(1), 55-85.
[44] Shehzad, K. A. \& Ismail, A. (2014). Value relevance of Accounting Information and its Impact on Stock Prices: Case Study of Listed Banks at Karachi Stock Exchange. Journal of Economic Information, 3(1), 40-48.

[45] Solomon, A.Z., Memba, F.S., \& Muturi, W.,(2016). Eanrings Per Share and Equity Share Investment in Companies Listed on Nigerian Stock Exchange. European Journal of Business, Economics and Accountancy, 4(1), 68-78.

[46] Uddin M. H., and Chowdhury G. M. (2005). Effect of Dividend Announcement on Shareholders' Value: Evidence from Dhaka Stock Exchange. Journal of Business Research, 7 (1), 61-72.

[47] Zakaria, Z., Muhammad, J., \& Zulkifli, A. (2012). The Impact of Dividend Policy on the Share Price Volatility: Malaysian Construction and Material Companies. International Journal of Economics and Management Sciences, 2(5), 01-08.

[48] Zayol, P.I, Mya A.I \&Muolozie, M., (2017). Determinant of Dividend Policy of Petroleum Firms in Nigeria. Journal of Economics and Finance, 8(3), 54-62. 